\title{
Total synthesis of (+)-epiquinamide
}

\author{
Marloes A. Wijdeven, Peter N. M. Botman, Roel Wijtmans, Hans E. Schoemaker, Floris \\ P. J. T. Rutjes, and Richard H. Blaauw*
}

Chiralix B. V., Toernooiveld 100, 6525 EC Nijmegen, The

Netherlands, and Radboud University Nijmegen, Institute for

Molecules and Materials, Toernooiveld 1, 6525 ED Nijmegen, The

Netherlands, and DSM Research, Life Sciences - Advanced Synthesis,

Catalysis and Development, P.O. Box 18, 6160 MD Geleen, The

Netherlands

richard.blaauw@chiralix.com

\section{Supporting Information}

General information: Unless noted otherwise, materials were purchased from commercial suppliers and used without purification. Dichloromethane was freshly distilled form calcium hydride. THF was freshly distilled from sodium benzophenone ketyl. All air and moisture sensitive reactions were carried out under an inert atmosphere of dry argon. Column chromatography was performed using Acros silica gel (0.035$0.070 \mathrm{~mm}$ ). TLC was performed using precoated_silica gel plates (Merck $60 \mathrm{~F}_{254}$ ). Optical rotations were measured on a Perkin-Elmer 241 polarimeter. Infrared spectra were recorded on an ATI Mattson Genesis FTIR spectrometer. ${ }^{1} \mathrm{H}$ NMR and ${ }^{13} \mathrm{C}$ NMR spectra were measured on a Bruker DPX200 (200 MHz), a Bruker DMX300 (300 and $75 \mathrm{MHz}$, respectively) or a Varian 400 (400 MHz). Spectra are reported in units of ppm on the $\delta$ scale. Mass spectra were measured using a JEOL JMS SX/SX102A four-sector mass spectrometer, coupled to a JEOL MS-MP7000 data system. Melting points are uncorrected.<smiles>C=CC[C@@H]1[C@@H](O)CC[C@@H](C(C)=O)N1C(=O)O[Na]</smiles>

5

To stirred solution of $\mathbf{3 a}^{1}(1.50 \mathrm{~g}, 4.60 \mathrm{mmol})$ in $\mathrm{CH}_{2} \mathrm{Cl}_{2}(45 \mathrm{~mL})$ were added allyltrimethylsilane (1.18 $\mathrm{mL}, 23 \mathrm{mmol})$ and $\mathrm{BF}_{3} \cdot \mathrm{OEt}_{2}(3.68 \mathrm{~mL}, 9.20 \mathrm{mmol})$ at $-30{ }^{\circ} \mathrm{C}$. The reaction mixture was warmed to $\mathrm{rt}$ and stirred for $2 \mathrm{~h}$, quenched with saturated aqueous $\mathrm{NaHCO}_{3}(50 \mathrm{~mL})$ and the aqueous phase was extracted with $\mathrm{CH}_{2} \mathrm{Cl}_{2}(2 \times 40 \mathrm{~mL})$. The combined organic phases were washed with brine $(50 \mathrm{~mL})$, dried over $\mathrm{Na}_{2} \mathrm{SO}_{4}$ and concentrated in vacuo. Flash chromatography (2:1-5:1 EtOAc:heptane) afforded product 5 as a colorless oil (1.40 g, $4.37 \mathrm{mmol}, 95 \%)$. [ $\alpha]_{\mathrm{D}}{ }^{24}-80.9$ (c 1.24, $\mathrm{CH}_{2} \mathrm{Cl}_{2}$ ). IR (film) 3451, 2950, 1735, 1696, 1412, 1296, 1208, $1010 \mathrm{~cm}^{-1} .{ }^{1} \mathrm{H}$ NMR $\left(300 \mathrm{MHz}, \mathrm{CDCl}_{3}\right.$, rotamers) $\delta$ 7.31-7.35 (m, 5H), 5.69-5.81 (m, $1 \mathrm{H}), 4.81-5.22(\mathrm{~m}, 5 \mathrm{H}), 4.18-4.29(\mathrm{~m}, 1 \mathrm{H}), 3.87-3.95(\mathrm{~m}, 1 \mathrm{H}), 3.61-3.75(\mathrm{~m}, 3 \mathrm{H}), 2.42(\mathrm{bs}, 1 \mathrm{H}), 2.04-2.16$ $(\mathrm{m}, 3 \mathrm{H}), 1.73-1.81(\mathrm{~m}, 1 \mathrm{H}), 1.57-1.70(\mathrm{~m}, 2 \mathrm{H})$. No clear ${ }^{13} \mathrm{C}$ NMR due to rotamers. HRMS $\left(\mathrm{FAB}^{+}\right)$: calcd for $\mathrm{C}_{18} \mathrm{H}_{24} \mathrm{NO}_{5}\left(M+\mathrm{H}^{+}\right)$: 334.1654, found: 334.1656 . 


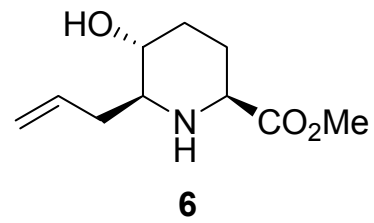

A solution of hydrogen bromide in acetic acid $(33 \mathrm{wt} \%, 50 \mathrm{~mL})$ was added to 5 (1.05 g, $3.27 \mathrm{mmol})$ and the resulting solution was stirred for $10 \mathrm{~min}$ at $0{ }^{\circ} \mathrm{C}$. The mixture was concentrated in vacuo, followed by the addition of $\mathrm{H}_{2} \mathrm{O}(40 \mathrm{~mL})$ and toluene $(40 \mathrm{~mL})$. The aqueous phase was washed with toluene $(2 \mathrm{x} 40 \mathrm{~mL})$ and concentrated in vacuo, (azeotropically evaporated twice with toluene). The product was dissolved in $\mathrm{MeOH}(32 \mathrm{~mL})$ and $\mathrm{K}_{2} \mathrm{CO}_{3}(587 \mathrm{mg}, 4.25 \mathrm{mmol})$ was added. The mixture was diluted with $\mathrm{H}_{2} \mathrm{O}(30 \mathrm{~mL})$ and $\mathrm{CH}_{2} \mathrm{Cl}_{2}(30 \mathrm{~mL})$ after $2 \mathrm{~h}$ and the aqueous phase was extracted with $\mathrm{CH}_{2} \mathrm{Cl}_{2}(3 \times 30 \mathrm{~mL})$. The combined organic layers were washed with brine $(60 \mathrm{~mL})$, dried over $\mathrm{Na}_{2} \mathrm{SO}_{4}$ and concentrated in vacuo. Crude product $6(547 \mathrm{mg}, 2.75 \mathrm{mmol}, 85 \%)$, obtained as a yellow oil, was used without further purification. ${ }^{1} \mathrm{H}$ NMR $\left(200 \mathrm{MHz}, \mathrm{CDCl}_{3}\right) \delta$ 5.76-5.96 (m, 1H), 5.16-5.28 (m, 2H), $3.75(\mathrm{~s}, 3 \mathrm{H}), 3.25-3.40(\mathrm{~m}, 2 \mathrm{H}), 2.71-$ $2.81(\mathrm{~m}, 1 \mathrm{H}), 2.40-2.50(\mathrm{~m}, 1 \mathrm{H}), 2.30(\mathrm{bs}, 2 \mathrm{H}), 2.09-2.22(\mathrm{~m}, 3 \mathrm{H}), 1.33-1.67(\mathrm{~m}, 2 \mathrm{H})$.<smiles>CC(=O)[C@H]1CC[C@@H](O)[C@H]2CCCC(=O)N12</smiles>

To a stirred solution of $6(574 \mathrm{mg}, 2.88 \mathrm{mmol})$ in $\mathrm{CH}_{2} \mathrm{Cl}_{2}(30 \mathrm{~mL})$ were added $\mathrm{Et}_{3} \mathrm{~N}(478 \mu \mathrm{L}, 3.46 \mathrm{mmol})$ and acryloyl chloride $(245 \mu \mathrm{L}, 3.02 \mathrm{mmol})$ at $-60{ }^{\circ} \mathrm{C}$. After $2 \mathrm{~h}$ the reaction mixture was quenched with $0.5 \mathrm{M}$ aqueous $\mathrm{Na}_{2} \mathrm{~S}_{2} \mathrm{O}_{5}(30 \mathrm{~mL})$ and warmed to rt. The organic phase was washed with $0.5 \mathrm{M}$ aqueous $\mathrm{Na}_{2} \mathrm{~S}_{2} \mathrm{O}_{5}(2 \times 30 \mathrm{~mL})$, saturated aqueous $\mathrm{NaHCO}_{3}(30 \mathrm{~mL})$ and brine $(30 \mathrm{~mL})$ and dried over $\mathrm{Na}_{2} \mathrm{SO}_{4}$. The solution was diluted with $\mathrm{CH}_{2} \mathrm{Cl}_{2}(110 \mathrm{~mL})$ where after argon was bubbled through, followed by the addition of Grubbs $2^{\text {nd }}$ generation ruthenium catalyst $(238 \mathrm{mg}, 0.29 \mathrm{mmol})$. After stirring overnight the mixture was concentrated in vacuo and dissolved in $\mathrm{MeOH}(30 \mathrm{~mL}) . \mathrm{Pd} / \mathrm{C}(31 \mathrm{mg}, 0.29 \mathrm{mmol})$ was added and the solution was stirred under $\mathrm{H}_{2}(1 \mathrm{~atm})$ for $2 \mathrm{~h}$. The reaction mixture was filtered over Celite and the solvent was evaporated under reduced pressure. Flash chromatography (100:0-95:5 $\left.\mathrm{CH}_{2} \mathrm{Cl}_{2}: \mathrm{MeOH}\right)$ afforded product 7 as a colorless oil $(380 \mathrm{mg}, 1.81 \mathrm{mmol}, 63 \%)$. $[\alpha]_{\mathrm{D}}{ }^{24}-91.0\left(c 0.48, \mathrm{CH}_{2} \mathrm{Cl}_{2}\right)$. IR (film) 3408, 2950, 2872, 1744, $1614 \mathrm{~cm}^{-1} .{ }^{1} \mathrm{H}$ NMR (400 MHz, $\left.\mathrm{CDCl}_{3}\right) \delta 3.98-4.00(\mathrm{~m}, 1 \mathrm{H}), 3.73(\mathrm{~s}, 3 \mathrm{H}), 3.66-$ $3.72(\mathrm{~m}, 1 \mathrm{H}), 3.19-3.24(\mathrm{~m}, 1 \mathrm{H}), 2.34-2.48(\mathrm{~m}, 2 \mathrm{H}), 2.26-2.32(\mathrm{~m}, 1 \mathrm{H}), 2.06-2.18(\mathrm{~m}, 2 \mathrm{H}), 1.86-1.97(\mathrm{~m}$, $2 \mathrm{H}), 1.79(\mathrm{~d}, J=5.1 \mathrm{~Hz}, 1 \mathrm{H}), 1.67-1.77(\mathrm{~m}, 2 \mathrm{H}), 1.45-1.54(\mathrm{~m}, 1 \mathrm{H}) .{ }^{13} \mathrm{C}$ NMR $\left(75 \mathrm{MHz}, \mathrm{CDCl}_{3}\right) \delta 171.2$, 171.0, 69.6, 60.6, 56.5, 52.0, 32.4, 30.2, 26.0, 23.7, 19.0. HRMS $\left(\mathrm{FAB}^{+}\right)$: calcd for $\mathrm{C}_{11} \mathrm{H}_{18} \mathrm{NO}_{4}\left(M+\mathrm{H}^{+}\right)$: 228.1236, found: 228.1226 .

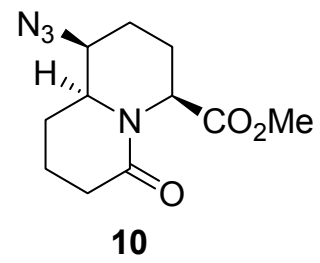

To a solution of $7(306 \mathrm{mg}, 1.46 \mathrm{mmol})$ in $\mathrm{CH}_{2} \mathrm{Cl}_{2}(15 \mathrm{~mL})$ were added $\mathrm{Et}_{3} \mathrm{~N}(263 \mu \mathrm{L}, 1.90 \mathrm{mmol})$ and methanesulfonyl chloride $(136 \mu \mathrm{L}, 1.75 \mathrm{mmol})$ at $0{ }^{\circ} \mathrm{C}$ and the reaction mixture was stirred for $1 \mathrm{~h}$. The reaction was quenched with saturated aqueous $\mathrm{NaHCO}_{3}(10 \mathrm{~mL})$, washed with brine $(2 \times 10 \mathrm{~mL})$, dried over $\mathrm{Na}_{2} \mathrm{SO}_{4}$ and concentrated in vacuo. The product was dissolved in DMF (15 mL), $\mathrm{NaN}_{3}(475 \mathrm{mg}, 7.3$ 
mmol) was added and the mixture was stirred at $100{ }^{\circ} \mathrm{C}$ for $18 \mathrm{~h}$. The reaction was allowed to cool to room temperature and diluted with $\mathrm{CH}_{2} \mathrm{Cl}_{2}(100 \mathrm{~mL}), \mathrm{H}_{2} \mathrm{O}(30 \mathrm{~mL})$ and brine $(30 \mathrm{~mL})$. The layers were separated and the organic phase was washed with $\mathrm{H}_{2} \mathrm{O}$ /brine $(1: 1,3 \times 50 \mathrm{~mL})$, dried over $\mathrm{Na}_{2} \mathrm{SO}_{4}$ and concentrated in vacuo. Flash chromatography (100:0-95:5 EtOAc:MeOH) afforded product $\mathbf{1 0}$ as a colorless oil (262 $\mathrm{mg}$, $1.15 \mathrm{mmol}, 79 \%)$. $[\alpha]_{\mathrm{D}}{ }^{21}+6.3\left(c 0.27, \mathrm{CH}_{2} \mathrm{Cl}_{2}\right)$. IR (film) 2946, 2863, 2094, 1731, 1640, 1333, $1165 \mathrm{~cm}^{-1}$. ${ }^{1} \mathrm{H}$ NMR $\left(300 \mathrm{MHz}, \mathrm{CDCl}_{3}\right) \delta$ 3.61-3.74 (m, 5H), 3.38-3.48 (m, 1H), 2.39-2.44 (m, 2H), 1.66-2.18 (m, 8H). ${ }^{13} \mathrm{C} \mathrm{NMR}\left(75 \mathrm{MHz}, \mathrm{CDCl}_{3}\right) \delta 171.9,170.4,59.7,58.3,56.9,51.8,32.5,26.8,26.3,22.1,19.6$. HRMS $\left(\mathrm{FAB}^{+}\right)$: calcd for $\mathrm{C}_{11} \mathrm{H}_{17} \mathrm{~N}_{4} \mathrm{O}_{3}\left(M+\mathrm{H}^{+}\right): 253.1301$, found: 253.1295 .<smiles>N[C@@H]1CCCN2C(=O)CCC[C@H]12</smiles>

11

To a solution of $\mathbf{1 0}(240 \mathrm{mg}, 0.95 \mathrm{mmol})$ in THF was added in 4 portions over $3 \mathrm{~h}, 1 \mathrm{M}$ aqueous $\mathrm{NaOH}$ $(6.7 \mathrm{~mL})$. The solution was then neutralized with $1 \mathrm{M}$ aqueous $\mathrm{HCl}$ to $\mathrm{pH}=7$, concentrated in vacuo and acidified to $\mathrm{pH}=2$ with $1 \mathrm{M}$ aqueous $\mathrm{HCl}$. The mixture was extracted with EtOAc $(3 \times 10 \mathrm{~mL})$ and the combined organic phases were dried over $\mathrm{Na}_{2} \mathrm{SO}_{4}$ and concentrated in vacuo. The crude product was dissolved in THF $(9 \mathrm{~mL})$ and cooled to $-15{ }^{\circ} \mathrm{C}$. Isobutyl chloroformate $(123 \mu \mathrm{L}, 0.95 \mathrm{mmol})$ and $N$ methylmorpholine $(104 \mu \mathrm{L}, 0.95 \mathrm{mmol})$ were added subsequently and the mixture was stirred for 5 minutes, followed by the addition of a solution of 2-mercaptopyridine- $N$-oxide (145 mg, $1.14 \mathrm{mmol}$ ) and $\mathrm{Et}_{3} \mathrm{~N}(158 \mu \mathrm{L}, 1.14 \mathrm{mmol})$ in THF $(24 \mathrm{~mL})$. The reaction mixture was stirred for $1 \mathrm{~h}$ with the exclusion of light, where after 2-methyl-2-propanethiol $(321 \mu \mathrm{L}, 2.85 \mathrm{mmol})$ was added and the mixture was exposed to a sun lamp $(250 \mathrm{~W})$ for $3 \mathrm{~h}$. The reaction was quenched with $\mathrm{H}_{2} \mathrm{O}(40 \mathrm{~mL})$ and extracted with $\mathrm{CH}_{2} \mathrm{Cl}_{2}(3 \times$ $40 \mathrm{~mL})$. The combined organic phases were washed with brine $(40 \mathrm{~mL})$, dried over $\mathrm{Na}_{2} \mathrm{SO}_{4}$ and concentrated in vacuo. Flash chromatography (100:0-95:5 EtOAc:MeOH) afforded 11 (91 mg, $0.47 \mathrm{mmol}$, $49 \%$ ) as a colorless oil. $[\alpha]_{\mathrm{D}}{ }^{24}-17.3\left(c 0.47, \mathrm{CH}_{2} \mathrm{Cl}_{2}\right)$. IR (film) 2941, 2860, 2094, $1618 \mathrm{~cm}^{-1} .{ }^{1} \mathrm{H}$ NMR $\left(300 \mathrm{MHz}, \mathrm{CDCl}_{3}\right) \delta 4.77-4.83(\mathrm{~m}, 1 \mathrm{H}), 3.64(\mathrm{~m}, 1 \mathrm{H}), 3.42-3.47(\mathrm{~m}, 1 \mathrm{H}), 2.31-2.47(\mathrm{~m}, 3 \mathrm{H}), 2.14-2.20(\mathrm{~m}$, $1 \mathrm{H}), 1.91-1.78(\mathrm{~m}, 3 \mathrm{H}), 1.73-1.77(\mathrm{~m}, 2 \mathrm{H}), 1.57-1.64(\mathrm{~m}, 2 \mathrm{H}) .{ }^{13} \mathrm{C} \mathrm{NMR}\left(75 \mathrm{MHz}, \mathrm{CDCl}_{3}\right) \delta 169.7,60.4$, 57.9, 41.6, 32.6, 28.5, 26.5, 19.4, 18.9. HRMS $\left(\mathrm{FAB}^{+}\right)$: calcd for $\mathrm{C}_{9} \mathrm{H}_{15} \mathrm{~N}_{4} \mathrm{O}\left(M+\mathrm{H}^{+}\right)$: 195.1246 , found: 195.1242 .

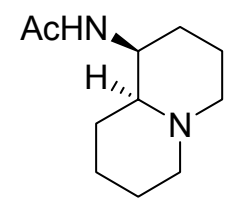

$(+)-1$

To a solution of $11(80 \mathrm{mg}, 0.41 \mathrm{mmol})$ in THF was added $\mathrm{LiAlH}_{4}(6.2 \mathrm{~mL}$ of a $1 \mathrm{M}$ soln. in THF, 6.2 $\mathrm{mmol}$ ) and the reaction was stirred overnight at $60{ }^{\circ} \mathrm{C}$. The reaction was carefully quenched by addition of $\mathrm{H}_{2} \mathrm{O}\left(305 \mathrm{mg}, 1.3 \mathrm{mg} / \mathrm{mg} \mathrm{LiAlH}_{4}\right)$, aqueous $\mathrm{NaOH}\left(15 \%\right.$ in $\left.\mathrm{H}_{2} \mathrm{O}, 305 \mathrm{mg}, 1.3 \mathrm{mg} / \mathrm{mg} \mathrm{LiAlH}_{4}\right)$ and again $\mathrm{H}_{2} \mathrm{O}\left(763 \mathrm{mg}, 3.25 \mathrm{mg} / \mathrm{mg} \mathrm{LiAlH}{ }_{4}\right)$. The resulting suspension was stirred vigorously for $10 \mathrm{~min}$, filtered and the filtrate was concentrated in vacuo. The residue was dissolved in dioxane $(4 \mathrm{~mL})$ and treated with $1 \mathrm{M}$ aqueous $\mathrm{NaOH}(4.1 \mathrm{~mL}, 4.1 \mathrm{mmol})$ and acetic anhydride $(194 \mu \mathrm{L}, 2.06 \mathrm{mmol})$. After stirring for $2 \mathrm{~h}$, the reaction mixture was diluted with saturated aqueous $\mathrm{NaHCO}_{3}(5 \mathrm{~mL})$ and $\mathrm{CH}_{2} \mathrm{Cl}_{2}(10 \mathrm{~mL})$. The layers were separated and the aqueous phase was extracted with $\mathrm{CH}_{2} \mathrm{Cl}_{2}(2 \times 10 \mathrm{~mL})$. The combined organic layers were dried over $\mathrm{Na}_{2} \mathrm{SO}_{4}$ and concentrated in vacuo, yielding (+)-epiquinamide 1 (68 mg, $0.35 \mathrm{mmol}$, $84 \%)$ as a white solid. Mp $124^{\circ} \mathrm{C} .[\alpha]_{\mathrm{D}}{ }^{20}+28\left(c 0.23, \mathrm{CHCl}_{3}\right)$. IR (film) 2933, 1652, 1539, 1444, 1456, 765 $\mathrm{cm}^{-1} .{ }^{1} \mathrm{H}$ NMR $\left(300 \mathrm{MHz}, \mathrm{CDCl}_{3}\right) \delta 6.15(\mathrm{bs}, 1 \mathrm{H}), 3.90-3.94(\mathrm{~m}, 1 \mathrm{H}), 2.73-2.80(\mathrm{~m}, 2 \mathrm{H}), 2.00(\mathrm{~s}, 3 \mathrm{H})$, 
1.84-1.96 (m, 4H), 1.73-1.70 (m, 2H), 1.38-1.58 (m, 5H), 1.23-1.36 (m, 2H). ${ }^{13} \mathrm{C}$ NMR $\left(75 \mathrm{MHz}, \mathrm{CDCl}_{3}\right) \delta$ 169.5, 64.3, 56.8, 56.7, 48.1, 29.6, 29.1, 25.6, 24.0, 23.4, 20.6. HRMS (FAB ${ }^{+}$: calcd for $\mathrm{C}_{11} \mathrm{H}_{21} \mathrm{~N}_{2} \mathrm{O}$ $\left(M+\mathrm{H}^{+}\right): 197.1654$, found: 197.1656

${ }^{1} \mathrm{H}$ NMR spectrum $\left(300 \mathrm{MHz}, \mathrm{CDCl}_{3}\right)$ of (+)-epiquinamide $\mathbf{1}$ :
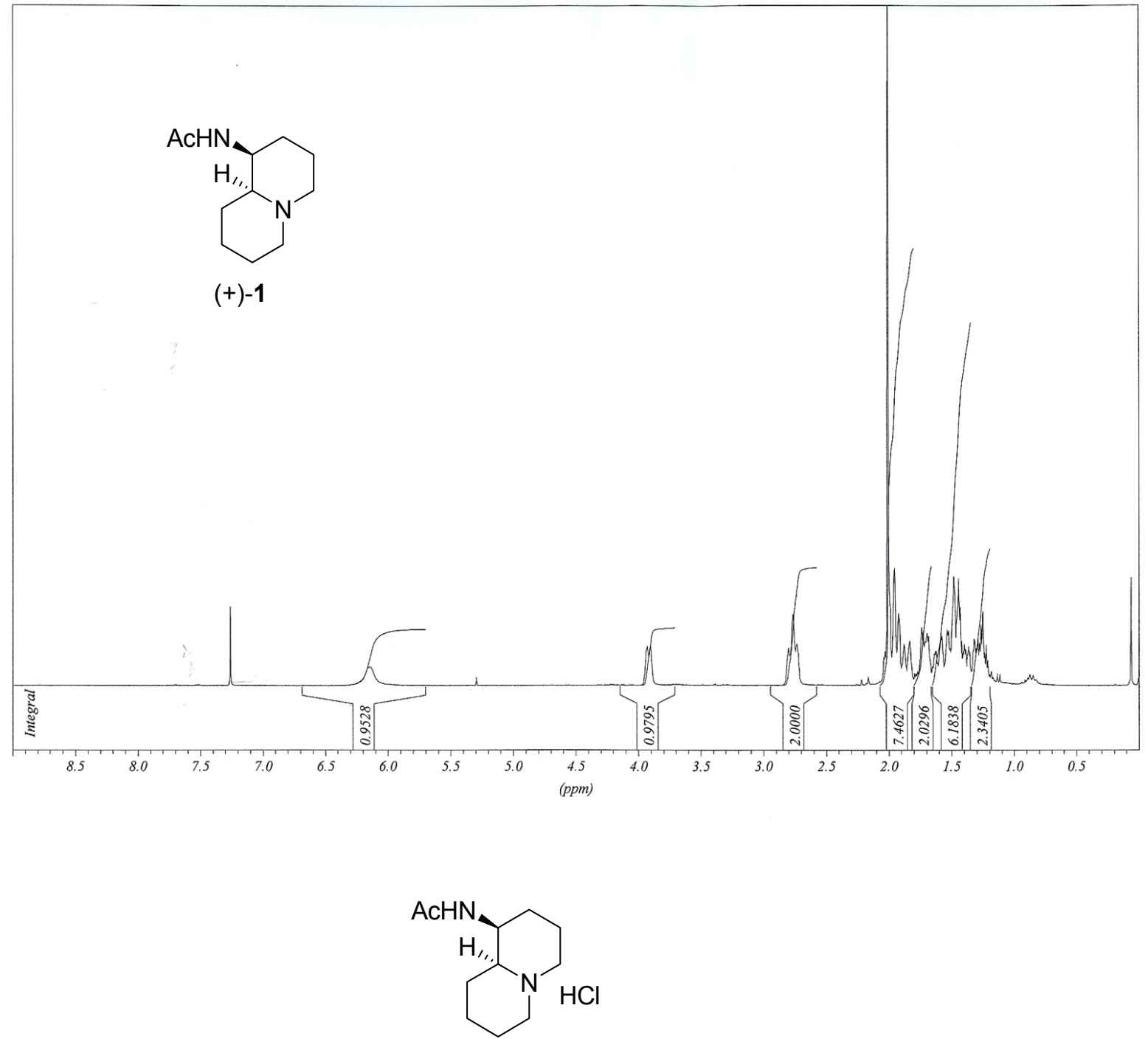

To compare the spectral of $(+)-\mathbf{1}$ with the literature data, ${ }^{2}$ the corresponding $\mathrm{HCl}$ salt was prepared according to the following procedure.

$(+)-1$ was dissolved in a saturated solution of $\mathrm{HCl}$ in EtOAc, and after 5 minutes the mixture was concentrated in vacuo, yielding the $\mathrm{HCl}$ salt of $(+)$-equinamide as a white solid. $\mathrm{Mp} 218^{\circ} \mathrm{C} .[\alpha]_{\mathrm{D}}{ }^{20}-15(c=$ $0.26, \mathrm{MeOH}$ ).

The ${ }^{1} \mathrm{H}$ NMR spectrum in $d_{6}$-acetone corresponded completely to the literature data. The ${ }^{1} \mathrm{H}$ NMR spectrum in $\mathrm{CD}_{3} \mathrm{OD}$ (also stated in the literature) differed slightly, due to the apparant omission of 1 proton in the literature data. ${ }^{1} \mathrm{H}$ NMR $\left(400 \mathrm{MHz}, \mathrm{CD}_{3} \mathrm{OD}\right) \delta 4.14(\mathrm{bs}, 1 \mathrm{H}), 3.29-3.35(\mathrm{~m}, 2 \mathrm{H}), 3.21-3.24(\mathrm{~m}, 1 \mathrm{H})$, 
2.86-2.93 (m, 2H), 2.02-2.08 (m, 1H), $1.96(\mathrm{~s}, 3 \mathrm{H}), 1.67-1.78(\mathrm{~m}, 7 \mathrm{H}), 1.60-1.64(\mathrm{~m}, 1 \mathrm{H})$ 1.48-1.57 (m, $1 \mathrm{H}) .{ }^{13} \mathrm{C} \mathrm{NMR}\left(75 \mathrm{MHz}, \mathrm{CD}_{3} \mathrm{OD}\right) \delta 174.3,67.4,57.8,56.7,49.2,29.9,29.1,25.2,24.0,23.7,20.37$.

\section{$\underline{\text { Reaction sequence according to Scheme } 3 .}$}<smiles>COC(=O)[C@H](CCCC1OCCO1)NC(=O)/C=C/c1ccccc1</smiles>

L-allysine ethylene acetal (4) $(5.0 \mathrm{~g}, 26 \mathrm{mmol})$ was suspended in dioxane $(12.5 \mathrm{~mL})$ and cooled to $0{ }^{\circ} \mathrm{C}$. A solution of $\mathrm{NaOH}(3.71 \mathrm{~g}, 91 \mathrm{mmol})$ in $\mathrm{H}_{2} \mathrm{O}(37.5 \mathrm{~mL})$ was added, followed by $\mathrm{NaHCO}_{3}(3.33 \mathrm{~g}, 26$ $\mathrm{mmol})$ and trans-cinnamoyl chloride $(6.50 \mathrm{~g}, 39 \mathrm{mmol}$, added in five portions over $5 \mathrm{~h})$. After stirring overnight the solvent was removed under reduced pressure, and a solution of $2.5 \%$ aqueous $\mathrm{NaHCO}_{3}(125$ $\mathrm{mL})$ was added. The aqueous solution was extracted with $\mathrm{Et}_{2} \mathrm{O}(3 \times 50 \mathrm{~mL})$, acidified by dropwise addition of $6 \mathrm{M}$ aqueous $\mathrm{HCl}$ to $\mathrm{pH}=3$ and the product was extracted with EtOAc $(3 \times 50 \mathrm{~mL})$. The combined organic layers were washed with brine $(50 \mathrm{~mL})$, dried over $\mathrm{Na}_{2} \mathrm{SO}_{4}$ and concentrated in vacuo. The crude product was then dissolved in DMF $(25 \mathrm{~mL})$, and $\mathrm{K}_{2} \mathrm{CO}_{3}(5.39 \mathrm{~g}, 39 \mathrm{mmol})$ was added portionwise at $0{ }^{\circ} \mathrm{C}$. The resulting suspension was stirred vigorously at $0{ }^{\circ} \mathrm{C}$ for $10 \mathrm{~min}$. Subsequently, MeI $(3.43 \mathrm{~mL}, 57 \mathrm{mmol})$ was added dropwise and stirring was continued for $2 \mathrm{~h}$ at $\mathrm{rt}$. The reaction mixture was quenched by addition of $\mathrm{H}_{2} \mathrm{O}(50 \mathrm{~mL})$, and the aqueous layer was extracted with EtOAc $(3 \times 50 \mathrm{~mL})$. The combined organic layers were washed with $0.5 \mathrm{M}$ aqueous $\mathrm{Na}_{2} \mathrm{~S}_{2} \mathrm{O}_{5}(50 \mathrm{~mL})$, brine $(50 \mathrm{~mL})$, dried over $\mathrm{Na}_{2} \mathrm{SO}_{4}$ and concentrated in vacuo to give product 8 as a white solid $(8.366 \mathrm{~g}, 25 \mathrm{mmol}, 97 \%)$. Mp $97{ }^{\circ} \mathrm{C}$. $[\alpha]_{\mathrm{D}}{ }^{21}+23.0$ (c $0.29, \mathrm{CH}_{2} \mathrm{Cl}_{2}$ ). IR (film) 3269, 2950, 2878, 1655, 1740, 1620, 1537, 1206, $1141 \mathrm{~cm}^{-1}$. ${ }^{1} \mathrm{H}$ NMR $(300$ $\left.\mathrm{MHz}, \mathrm{CDCl}_{3}\right) \delta 7.57(\mathrm{~d}, J=15.6 \mathrm{~Hz}, 1 \mathrm{H}), 7.41-7.43(\mathrm{~m}, 2 \mathrm{H}), 7.28-7.30(\mathrm{~m}, 3 \mathrm{H}), 6.56(\mathrm{~d}, J=7.8 \mathrm{~Hz}, 1 \mathrm{H})$, $6.44(\mathrm{~d}, J=15.6 \mathrm{~Hz}, 1 \mathrm{H}), 4.71-4.81(\mathrm{~m}, 2 \mathrm{H}), 3.86-3.90(\mathrm{~m}, 2 \mathrm{H}), 3.78-3.85(\mathrm{~m}, 2 \mathrm{H}), 3.73(\mathrm{~s}, 3 \mathrm{H}), 1.89-1.94$ $(\mathrm{m}, 1 \mathrm{H}), 1.75-1.80(\mathrm{~m}, 1 \mathrm{H}), 1.65-1.69(\mathrm{~m}, 2 \mathrm{H}), 1.45-1.55(\mathrm{~m}, 1 \mathrm{H}) .{ }^{13} \mathrm{C} \mathrm{NMR}\left(75 \mathrm{MHz}, \mathrm{CDCl}_{3}\right) \delta 172.3$, $164.9,141.0,134.1,129.2,128.2$, 127.3, 119.6, 103.6, 64.5, 52.2, 52.0, 33.1, 32.1, 19.7. HRMS $\left(\mathrm{FAB}^{+}\right)$: calcd for $\mathrm{C}_{18} \mathrm{H}_{24} \mathrm{NO}_{5}\left(M+\mathrm{H}^{+}\right): 334.1654$, found: 334.1656 .

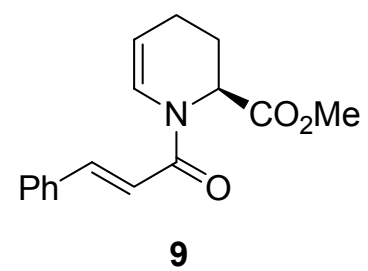

Compound 8 (1.67 g, $5.0 \mathrm{mmol})$ was dissolved in TFA $(25 \mathrm{~mL})$ and the mixture was stirred for $10 \mathrm{~min}$. The reaction mixture was quenched with saturated aqueous $\mathrm{NaHCO}_{3}(250 \mathrm{~mL})$ and extracted with EtOAc $(3 \times 100 \mathrm{~mL})$. The combined organic phases were washed with brine $(100 \mathrm{~mL})$, dried over $\mathrm{Na}_{2} \mathrm{SO}_{4}$ and the solvent was evaporated under reduced pressure. Product $9(1.36 \mathrm{~g})$ was obtained as a yellow oil which was used without further purification. ${ }^{1} \mathrm{H} \mathrm{NMR}\left(300 \mathrm{MHz}, \mathrm{CDCl}_{3}\right.$, rotamers $) \delta 7.71(\mathrm{~d}, J=15.3 \mathrm{~Hz}, 1 \mathrm{H}), 7.50$ $7.52(\mathrm{~m}, 2 \mathrm{H}), 7.31-7.37(\mathrm{~m}, 3 \mathrm{H}), 6.93(\mathrm{~d}, J=15.3 \mathrm{~Hz}, 1 \mathrm{H}), 6.88(\mathrm{~d}, J=8.4 \mathrm{~Hz}, 1 \mathrm{H}), 5.31-5.33$ and 5.11$5.13(2 \times \mathrm{m}, 1 \mathrm{H}), 4.99-5.03$ and 4.89-4.91 $(2 \times \mathrm{m}, 1 \mathrm{H}), 3.73-3.74(\mathrm{~m}, 3 \mathrm{H}), 2.34-2.44(\mathrm{~m}, 1 \mathrm{H}), 1.91-2.07$ $(\mathrm{m}, 3 \mathrm{H})$. 


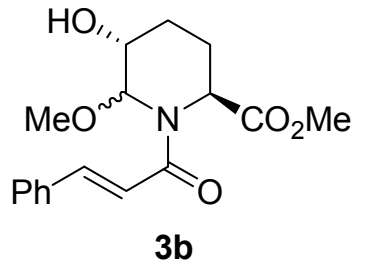

A solution of $9(1.36 \mathrm{~g})$ in $\mathrm{MeOH}(10 \mathrm{~mL})$ was added to a suspension of Oxone $(4.04 \mathrm{~g}, 6.57 \mathrm{mmol})$ and $\mathrm{NaHCO}_{3}(637 \mathrm{mg}, 7.57 \mathrm{mmol})$ in $\mathrm{MeOH}(10 \mathrm{~mL})$. The mixture was stirred overnight, after which solids were removed by filtration. The filtrate was diluted with $\mathrm{CH}_{2} \mathrm{Cl}_{2}(30 \mathrm{~mL})$ and saturated aqueous $\mathrm{NaHCO}_{3}$ $(30 \mathrm{~mL})$. The layers were separated and the aqueous phase was extracted with $\mathrm{CH}_{2} \mathrm{Cl}_{2}(2 \times 30 \mathrm{~mL})$. The combined organic layers were washed with brine $(50 \mathrm{~mL})$, dried over $\mathrm{Na}_{2} \mathrm{SO}_{4}$ and concentrated in vacuo. Product 3b (1.18 g) was obtained as yellow oil which was used without further purification. ${ }^{1} \mathrm{H}$ NMR (300 $\mathrm{MHz}, \mathrm{CDCl}_{3}$, rotamers) $\delta$ 7.64-7.74 $(\mathrm{m}, 1 \mathrm{H}), 7.45-7.47(\mathrm{~m}, 2 \mathrm{H}), 7.30-7.32(\mathrm{~m}, 3 \mathrm{H}), 6.89-7.02(\mathrm{~m}, 1 \mathrm{H})$, 5.69-5.71 and 5.37-5.39 $(2 \times \mathrm{m}, 1 \mathrm{H}), 5.11-5.12$ and 4.58-4.60 $(2 \times \mathrm{m}, 1 \mathrm{H}), 3.95-3.96(\mathrm{~m}, 1 \mathrm{H}), 3.69-3.72$ $(\mathrm{m}, 3 \mathrm{H}), 3.26-3.31(\mathrm{~m}, 3 \mathrm{H}), 1.98-2.17(\mathrm{~m}, 3 \mathrm{H}), 1.61-1.65(\mathrm{~m}, 1 \mathrm{H})$.<smiles>C=CC[C@H]1[C@@H](O)CC[C@@H](C(C)=O)N1C(=O)/C=C/c1ccccc1</smiles>

A solution of $\mathbf{3 b}(1.18 \mathrm{~g})$ in $\mathrm{CH}_{2} \mathrm{Cl}_{2}(40 \mathrm{~mL})$ was cooled to $-30{ }^{\circ} \mathrm{C}$. Allyltrimethylsilane $(2.6 \mathrm{~mL}, 18$ mmol) and $\mathrm{BF}_{3} \cdot \mathrm{OEt}(0.95 \mathrm{~mL}, 7.5 \mathrm{mmol})$ were added subsequently and the mixture was allowed to warm to rt. The reaction mixture was quenched with saturated aqueous $\mathrm{NaHCO}_{3}(40 \mathrm{~mL})$ after stirring for $2 \mathrm{~h}$. The layers were separated and the organic phase was washed with $\mathrm{H}_{2} \mathrm{O}(25 \mathrm{~mL})$ and brine $(25 \mathrm{~mL})$, dried over $\mathrm{Na}_{2} \mathrm{SO}_{4}$ and concentrated in vacuo. Product $\mathbf{2 b}(1.18 \mathrm{~g})$ was obtained as a yellow oil which was used without further purification. ${ }^{1} \mathrm{H} \mathrm{NMR}\left(300 \mathrm{MHz}, \mathrm{CDCl}_{3}\right.$, rotamers) $\delta 7.70-7.78(\mathrm{~m}, 1 \mathrm{H}), 7.48-7.51(\mathrm{~m}, 2 \mathrm{H})$, 7.36-7.38 $(\mathrm{m}, 3 \mathrm{H}), 6.90-6.95(\mathrm{~m}, 1 \mathrm{H}), 5.78-5.95(\mathrm{~m}, 1 \mathrm{H}), 5.55-5.58$ and 4.76-4.86 $(2 \mathrm{x} \mathrm{m}, 1 \mathrm{H}), 5.03-5.25$ $(\mathrm{m}, 2 \mathrm{H}), 3.98-4.02(\mathrm{~m}, 1 \mathrm{H}), 3.72-3.76(\mathrm{~m}, 3 \mathrm{H}), 2.40-2.44(\mathrm{~m}, 1 \mathrm{H}), 2.11-2.32(\mathrm{~m}, 2 \mathrm{H}), 1.90-2.01(\mathrm{~m}, 1 \mathrm{H})$, $1.77-1.67(\mathrm{~m}, 3 \mathrm{H})$.<smiles>COC(=O)[C@@H]1CC[C@@H](O)[C@H]2CCCC(=O)N12</smiles>

Compound $2 \mathbf{b}(1.18 \mathrm{~g})$ was dissolved in toluene $(180 \mathrm{~mL})$ and the solution was degassed by bubbling through with argon for $10 \mathrm{~min}$. Then, Grubbs $2^{\text {nd }}$ generation ruthenium catalyst $(154 \mathrm{mg}, 0.36 \mathrm{mmol})$ was added. The reaction mixture was stirred overnight and concentrated in vacuo. The residue was dissolved in $\mathrm{MeOH}(36 \mathrm{~mL}), \mathrm{Pd} / \mathrm{C}(38 \mathrm{mg}, 0.36 \mathrm{mmol})$ was added and the mixture was stirred under an atmosphere of $\mathrm{H}_{2}$ for $2 \mathrm{~h}$. Next, the mixture was filtered over Celite and the solvent was evaporated under reduced pressure. Flash chromatography (100:0-95:5 EtOAc:MeOH) afforded product 7 as a colorless oil (250 mg, $1.10 \mathrm{mmol}, 22 \%$ over 5 steps).

1 Botman, P. N. M.; Dommerholt, F. J.; de Gelder, R.; Broxterman, Q. B.; Schoemaker, H. E.; Rutjes, F. P. J. T.; Blaauw, R. H. Org. Lett. 2004, 6, 4941.

2 Fitch, R. W.; Garraffo, H. M.; Spande, T. F.; Yeh, H. J. C.; Daly, J. W. J. Nat. Prod. 2003, 66, 1345. 